\title{
Ethanol of ajwa
}

\author{
M. Dede Rodliyana ${ }^{1}$, Saepudin Rahmatullah", ${ }^{2, *}$ Dudang Gojali ${ }^{3}$, Ecep Ismail $^{1}$, and Risma Nur Apipah $^{2}$ \\ ${ }^{1}$ Fakultas Ushuluddin UIN Sunan Gunung Djati Bandung, Jl A.H. Nasution No. 105, Bandung 40614, Indonesia \\ ${ }^{2}$ Prodi Pendidikan Kimia UIN Sunan Gunung Djati Bandung, J1 A.H. Nasution No. 105, Bandung 40614, Indonesia \\ ${ }^{3}$ Fakultas Syariah dan Hukum UIN Sunan Gunung Djati Bandung, Jl A.H. Nasution No. 105, Bandung 40614, Indonesia
}

\begin{abstract}
Dates ajwa is a special fruit. One of the obvious advantages listed in the hadith of Rasulullah SAW. In addition, the glucose content is very high, thus potentially producing ethanol after fermentation. Selfexplanatory calendar searches as ethanol producers have not been reported, so they need to be explored. This study traces ethanol to fermented dates with hydrolysis and without hydrolysis. The results showed that the volume of ethanol produced by hydrolysis was larger, ie $15.5 \mathrm{~mL} /$ day, compared without hydrolysis, ie as much as $6.5 \mathrm{~mL} /$ day. In the flame test, the fermentation results with hydrolysis longer lit than without hydrolysis. The benefits of the study provide information that dates as well as rizki ajwa, also can produce intoxicating substances.
\end{abstract}

\section{Introduction}

Dates are one of the ten fruit species mentioned in the Qur'an [1]. Ajwa is one type of dates (Phoenix dactylifera). This fruit is often called the Rosul date, because the tree is only in madinah and the person who first introduced is Prophet Muhammad SAW. The hadith of the Prophet SAW reveals the virtue of this fruit, that if consumed as much as 3 or 7 can ward off magic [2], and then in another hadith mentioned this fruit can serves as medicine [3]. As Mallaping's research, et al., shows that the potential of dates can recover blood lactate, so that the dates can be used as an alternative food source for workers to increase their productivity through efficient recovery of fatigue [4]. The same study was conducted by Sani, et al., indicating that dates can be used as dietary supplements and antimicrobial agents [5]. In line with research Hamada et al., that Pits of date palm could be an excellent source of functional foods components with the exclusion of phytic acid [6].

In addition to these virtues, these fruits contain very high sugar, is glucose content 51.3 grams / 100 grams and 48.5 grams $/ 100$ grams for the content of sucrose [7] and according Kamarudin et al., revealed that glucose contained about $20-70 \%$ in dry weight [8].

Meanwhile, the potential of date palms other than as a good food, can also intoxicating (QS Al Nahl 76). Potentially intoxicating suspected because of high glucose content. As research conducted by S. Awe and SN Nnadoze, which indicates that the palm fruit can be used as fruit wine with a good microbiological standart [9]. In line with other research performed by Bhusari, et al., which showed that the palm fruit can be used as a wine with a good microbiological standart [10].

Potential dates browsing as an intoxicating substance has not been widely reported, on the basis of this, it is worth exploring the potential of ajwa dates to produce intoxicating substances.

\section{Methods}

\subsection{Qualitative Analysis of Sugar Content at Ajwa Dates}

\subsubsection{Ajwa Dates Hydrolysis}

Dates that have been separated seeds cut then dried in the heat sun and oven. Then ground to a certain size. Dried dried fruit weighed 25 grams and then put into $250 \mathrm{ml}$ Erlenmeyer. Into Erlenmeyer added $50 \mathrm{ml} \mathrm{H}_{2} \mathrm{SO}_{4} 1 \%$ and erlenmeyer sealed with cork and then heated at $121^{\circ} \mathrm{C}$ for 30 minutes. Separated water phase was then added 100 $\mathrm{ml}$ of $4 \% \mathrm{NaOH}$ and closed tightly and reheated at $121^{\circ} \mathrm{C}$ for 30 minutes. The solid phase was washed with water several times.

\subsubsection{Fermentation Process}

The hydrolyzed date palm fruit juice is added with 4 grams of Saccaromyces Cerevisiae and stirred at $150 \mathrm{rpm}$ until homogeneous. After that Erlemeyer $250 \mathrm{ml}$ containing the date palm is connected to a rubber hose and the end of the hose is inserted into the water to avoid direct contact with air. Furthermore the solution is fermented for 1 day, 3 days and 5 days (according to treatment). The solution is separated by a date slurry so that the alcohol and water liquor are obtained.

*Correcponding author : saep.rh@uinsgd.ac.id 


\subsubsection{Purification of Ethanol (Distillation)}

The obtained ethanol is purified by distillation. The fermented liquid is fed into the distillation flask and then heated to a temperature of $80^{\circ} \mathrm{C}$. The distillation process is carried out for 1.5 - 2 hours until ethanol does not drip again. The distilled ethanol is measured.

\subsubsection{Analysis of Bioethanol Dates}

a. Qualitative

The purified bioethanol is introduced into $5 \mathrm{ml}$ porcelain cup then in flame test.

b. Quantitative

Bioethanol was measured with GC-MS to determine the resulting ethanol content.

\section{Result and Discussion}

Date palms contain very high sugar, is glucose content $51.3 \mathrm{gram} / 100$ gram and $48.5 \mathrm{gram} / 100$ gram for the content of sucrose [11]. The presence of sugar content on ajwa dates is evidenced by the positive results of the Molisch, Barfoed and Benedict tests shown in Table 1.

Table 1. Qualitative Test of Sugar Content.

\begin{tabular}{|c|c|c|c|c|}
\hline \multirow{2}{*}{\multicolumn{2}{|c|}{ Dates Extract }} & \multicolumn{3}{|c|}{ Qualitative Testing } \\
\hline & & \multirow{2}{*}{$\begin{array}{c}\text { Molisch } \\
\text { Test } \\
+\end{array}$} & \multirow{2}{*}{$\begin{array}{c}\text { Barfoed } \\
\text { Test } \\
+ \\
\end{array}$} & \multirow{2}{*}{$\begin{array}{c}\text { Benedict } \\
\text { Test } \\
+\end{array}$} \\
\hline & Aquadest & & & \\
\hline$\frac{3}{\circ}$ & Ethanol & + & + & + \\
\hline
\end{tabular}

Sugar content in high dates is a potential raw material for ethanol production [12]. Bioethanol is produced from sugar which is the result of fermentation activity of yeast cells. A good yeast used to produce an bioethanol is from the genus Saccharomyces. Saccharomyces cerevisiae produces zimase and invertase enzymes. Zimase enzyme serves as the breaking of sucrose into monosaccharides (glucose and fructose). The invertase enzyme further converts glucose to an bioethanol [13]. Sugar content of $10-18 \%$ in the fermentation medium generally produces a lot of ethanol.

The qualitative test of ethanol content on fermented dates is evidenced by positive results on flame test, due to the flammability of ethanol.

Additionally, ethanol from fermented palm ajwa analyzed by GC-MS. The GC-MS spectra in Figure 1 shows that the sample of the experimental results has two peaks. It shows that the first distillation product on the bioethanol is not $100 \%$ pure ethanol. At the time of retention 1,365 there is the first peak which indicates the presence of ethanol. While at retention time of 1.581 there is a second peak indicating the presence of chloroform compound. To find out what compounds are present in the sample, it can be known from the GC-MS libraries presented in Figures 2 and $\mathbf{3}$.

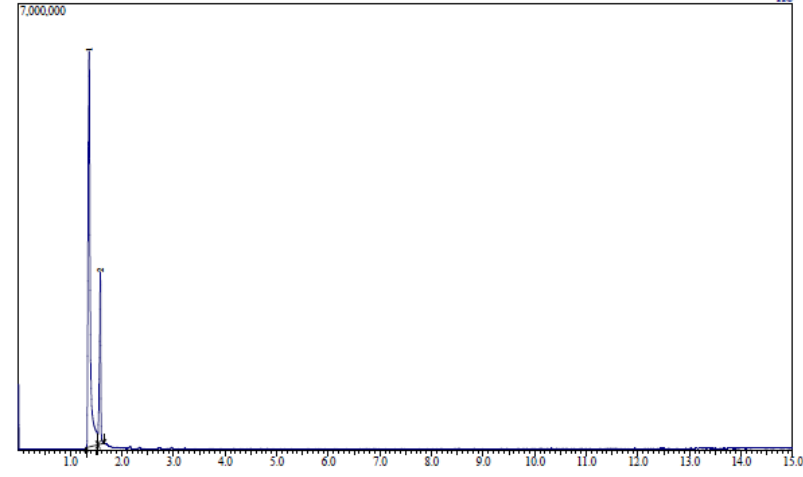

Fig. 1. Results of GC-MS Chromatogram of Bioethanol Samples.

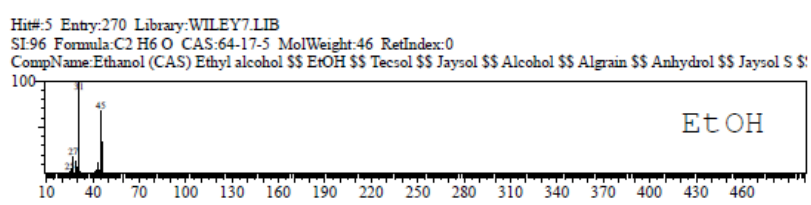

Fig. 2. The ethanol spectrum of the GC-MS Instrument Library.

Hitt:5 Enty:14463 Library:WILEY7.LIB

SI:93 Formula:C H CL3 CAS:67-66-3 MolWeight:118 RetIndex:0

CompName:Chloroform SS Methane, trichloro- (CAS) R 20 SS Freon 20 SS Trichloroform S\$ Trichloromethane SS R 20

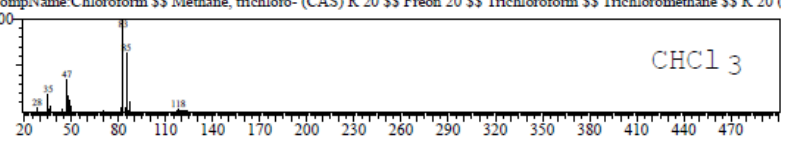

Fig. 3. The chloroform spectrum of the GC-MS Instrument Library.

Based on the chromatogram of Figure. 2 it can be ascertained that the sample of the experimental results contained a bioethanol compound. This is evidenced by the ethanol relative molecular formula $\left(\mathrm{C}_{2} \mathrm{H}_{5} \mathrm{OH}\right)$ is 46 as shown in the spectrum.

Ethanol produced from the fermentation of the ajwa dates is indicated in Table 2.

Table 2. The volume of ethanol produced by day.

\begin{tabular}{|c|c|c|c|c|}
\hline \multirow[t]{2}{*}{ Treatment } & \multirow{2}{*}{$\begin{array}{c}\text { Initial } \\
\text { Volume } \\
\text { (ml) }\end{array}$} & \multicolumn{3}{|c|}{$\begin{array}{l}\text { Volume ethanol } \\
(\mathrm{ml}) / \text { day }\end{array}$} \\
\hline & & 1 & 3 & 5 \\
\hline Hydrolysis & 100 & 2.0 & 7.0 & 13.5 \\
\hline $\begin{array}{l}\text { Without } \\
\text { Hydrolysis }\end{array}$ & 100 & 1.0 & 3.0 & 6.3 \\
\hline
\end{tabular}

Based on Table 1 shows that the highest bioethanol volume get on the fermentation time of 5 days. Time fermentation has an effect on which bioethanol yields are getting longer fermentation time then the bioethanol will increase. However, when fermentation is too long then the nutrients in the substrate will be exhausted and yeast Saccaromyces cerevisiae can no longer ferment the ingredients.

In addition, the amount of ethanol produced by hydrolysis is more that $15.5 \mathrm{~mL}$ /day compared with without hydrolysis ie $6.5 \mathrm{~mL} /$ day. This is because the process of hydrolysis or called saccharification can break down complex carbohydrates (like sugar, cellulose and hemisolulose into sugar monomers) into simpler 
components. Therefore, at the time of the fermentation process, the yeast used will directly degrade the glucose of the hydrolysis result so that the fermentation process runs optimally to produce more ethanol.

\section{Conclusion}

Dates have the potential to produce ethanol as evidenced by flame tests and GC-MS test results. The ethanol volume resulting from the fermentation of ajwa dates with hydrolysis was higher at $15.5 \mathrm{~mL} /$ day, compared with no hydrolysis ie $6.5 \mathrm{~mL} /$ day.

We ackonledge to UIN Sunan Gunung Djati Bandung.

\section{References}

1. Marwat, et al., "Fruit Plant Species Mentioned in the Holy Qur'an and Ahadith and Their Ethnomedicinal Importance, American-Eurasian Journal Agriculture \& Environtment Science, Vol. 5, no. 2, pp. 284-295, (2009)

2. HR Al-Bukhari (no. 5769) dan Muslim (no. 2047) (155), dari Shahabat Sa'ad bin Abu Waqqash.

3. HR Ibnu Majah (no. 3453) Ahmad (III/48) dari Sahabat Jabir bin Abdillah dan Abi Sa'id, demikian juga At-Tirmidzi dalam Sunnannya (no. 2066) dari Abu Hurairah. Dishahihkan oleh Syaikh Al-Albani dalam Misykatul Mashaabiih (IV/164/4163), dimuat juga oleh Syaikh Salim bin Ied Al-Hilaly dalam Shahih Ath-Thibb An-Nabawy fi Dhau'il Ma'arif Ath-Thabiyyah wal Ilmiyyah Al-Haditsah (hal. 428), cet. Maktabah Al-Furqaan, (th.1424H)

4. Mallapiang, Fatmawaty, et al., " Effectiveness of Ajwa Date (Phoenix dactylifera) on Blood Lactate Recovery in Rats (Rattusnorvergicus) with Induced Physical Activity," IJSBAR., vol. 24, no. 7, pp. 134142, (2015)

5. Sani, et al.," Date Palm (Phoenix dactylifera) as food supplement and antimicrobial Agent in the 21st Century - A review," Journal of Pharmacy and Biological Sciences, vol.11, no. 4, pp. 46-51, 2016.

6. Hamada, et al., "Preliminary analysis and potential uses of date pits in foods," Food Chemistry, no. 76, pp. 135-137, (2002)

7. Moh. Erfan Soebahar, dkk., "Mengungkap Rahasia Buah Kurma Dan Zaitun Dari Petunjuk Hadits Dan Penjelasan Sains", Ulul Albab, vol. 16, no. 2, (2015)

8. Kamarudin, et al., "Phoenix dactylifera: Discoveries through the Eyes of Science," Seminar On Religion And Science, (2014)

9. Awe, S., \& Nnadoza, S. N, "Production and Microbiological Assesment of Date Palm (Phoenix dactylifera L.) Fruit Wine," British Microbiology Research Journal, vol. 3, no. 8, 480-488, (2015)

10. Bhusari, et al., "Fermentation and characterization of wine from fruits of Pheonix dactylifera, using Saccaromyces cerevisae NCIM 3495," International Food Research Journal, vol. 20, no. 6, pp. 34113415 , (2013)
11. Assirey, E. A., "Nutritional composition of fruit of 10 date palm (Phoenix dactylifera L.) cultivars grown in Saudi Arabia," Jurnal of Taliban University, (2015)

12. Seftian, Deky, dkk., "Pembuatan Etanol dari Kulit Pisang Menggunakan Metode Hidrolisis Enzimatik dan Fermentasi," Jurnal Teknik Kimia, vol. 18, no. 1, pp. 10-16, (2012)

13. Sebayang, Firman, "Pembuatan Etanol dari Molase Secara Fermentasi Menggunakan Sel Saccharomyses Cerevisiae yang Termobilisasi pada Kalsium Alginat," Jurnal Teknologi Proses, vol. 5, no. 2, pp. 75-80, (2006) 